\title{
A European Perspective on the International Human Rights and Humanitarian Law Relationship in the Context of Multinational Military Operations
}

\author{
Gentian Zyberi* and Anna Andersson ${ }^{* *}$
}

\section{Introduction}

The nature of the relationship between international human rights law $(\mathrm{IHRL})$ and international humanitarian law (IHL) has drawn significant interest in different professional circles, including academia, military, governments, international and regional organizations and agencies, and humanitarian organizations and their workers. ${ }^{1}$ This chapter will analyse, from a European perspective, this complex relationship in the context of multinational military operations. This is quite important, since many European states have participated in such operations in different

* Professor of International Law and Human Rights, Norwegian Centre for Human Rights, University of Oslo; Gentian.Zyberi@nchr.uio.no.

** PhD candidate, Norwegian Centre for Human Rights, University of Oslo; Anna.Andersson@nchr.uio.no. The authors would like to thank the editors for their feedback. All websites accessed on 17 December 2018.

${ }^{1}$ For academic commentary see inter alia René Provost, International human rights and humanitarian law (Cambridge University Press 2002); Heike Krieger, 'A conflict of norms: The relationship between humanitarian law and human rights law in the ICRC customary law study' [2006] 11 Journal of Conflict and Security Law 265; Roberta Arnold and Noëlle Quénivet (eds), International humanitarian law and human rights law: Towards a new merger in international law (Brill, Nijhoff 2008); Alexander Orakhelashvili, 'The interaction between human rights and humanitarian law: Fragmentation, conflict, parallelism, or convergence?' [2008] 19 European Journal of International Law 161-182; Françoise Hampson, 'The Relationship between International Humanitarian Law and Human Rights Law from the Perspective of a Human Rights Treaty Body' [2008] 90 International Review of the Red Cross (hereafter IRRC) 549-572; Orna Ben-Naftali (ed), International humanitarian law and international human rights law: Pas de deux (OUP 2011); Sir Daniel Bethlehem QC, 'The relationship between international humanitarian law and international human rights law in situations of armed conflict' [2013] 2(2) Cambridge Journal of International and Comparative Law 180-195; Tristan Ferraro, 'The applicability and application of international humanitarian law to multinational forces' [2013] 95 IRRC 561-612; Lijiang Zhu, 'International Humanitarian Law in the Universal Periodic Review of the UN Human Rights Council: An Empirical Survey' [2014] 5 Journal of International Humanitarian Legal Studies 186-212; Terry D. Gill, Dieter Fleck (eds), The Handbook of the International Law of Military Operations (2nd edt, OUP 2015); Terry Gill and others (eds), Leuven Manual on the International Law Applicable to Peace Operations (Cambridge University Press 2017). For the inclusion of human rights in military manuals, see among others Louise Doswald-Beck and Sandra Krähenmann, 'Incorporating International Human Rights Law' in Nobuo Hayashi (ed), National Military Manuals on the Law of Armed Conflict (2 ${ }^{\text {nd }}$ edt, Torkel Opsahl Academic EPublisher 2010) 157171. See also the ICRC, Handbook on International Rules Governing Military Operations (ICRC, 2016); 'IHL and human rights', at <www.icrc.org/en/war-and-law/ihl-other-legal-regmies/ihl-human-rights>; UN Office of the High Commissioner for Human Rights 'International legal protection of human rights in armed conflict' (New York and Geneva, 2011) $<$ www.ohchr.org/Documents/Publications/HR_in_armed_conflict.pdf>. 
parts of the world in the context of operations led by the $\mathrm{UN}^{2}{ }^{2}$ the $\mathrm{EU} ;{ }^{3}$ as part of North-Atlantic Treaty Organization (NATO); ${ }^{4}$ or by the United States. In construing a European perspective, the case law of the European Court of Human Rights (ECtHR) is given specific attention, since all European states are bound by the European Convention on Human Rights (ECHR), and the EU is in the process of becoming a party to this convention. Our analysis also takes into account relevant legal documents by organs of the Council of Europe (CoE) and of the EU, as well as practice by European states involved in multinational military operations. While our focus remains on the European perspective at a regional level, ${ }^{5}$ due attention is paid to the international level, especially positions taken by UN organs or the International Committee of the Red Cross (ICRC). This chapter takes an instrumental approach, inquiring whether and to what extent the convergence between human rights and humanitarian law helps ensuring a higher level of protection for civilians and civilian objects from the effects of armed conflicts, both international (IAC) and non-international (NIAC).

After discussing the shared foundational value of both these branches of international law, namely protecting human dignity (2.), the degree of convergence between IHRL and IHL is assessed in three main areas which are of significant relevance to the conduct of such operations: the protection of civilians (3.), the right to humanitarian assistance (4.), and the right to reparations for victims of armed conflicts (5.). ${ }^{6}$ This substantive convergence is driven by several shared core concerns, specifically safeguarding human dignity, ensuring the protection of life and bodily integrity, and reducing as much as possible material damage to private and public property and to cultural heritage objects. The progressive trend towards the so-called 'humanization' of international legal obligations, ${ }^{7}$ consisting of using basic concepts and human rights instruments and practices as subsidiary means of interpretation for filling in legal gaps, contributes to the substantive convergence between IHL and IHRL.

${ }^{2}$ For more information, see <https://peacekeeping.un.org/en>.

3 For more information, see <https://eeas.europa.eu/topics/military-and-civilian-missions-andoperations_en>.

${ }^{4}$ For more information, see <https://www.nato.int/cps/en/natohq/topics_52060.htm>.

${ }^{5}$ See among others Karin Oellers-Frahm, 'A regional perspective on the convergence and conflicts of human rights and international humanitarian law in military operations: The European Court of Human Rights' in Erika de Wet and Jann Kleffner (eds), Convergence and Conflicts of Human Rights and International Humanitarian Law in Military Operations (Pretoria University Law Press 2014) 333-363; Andrea Gioia, 'The Role of the European Court of Human Rights in Monitoring Compliance with Humanitarian Law in Armed Conflict' in Orna Ben-Naftali (ed), International Humanitarian Law and International Human Rights Law: Pas de Deux (OUP 2011) 201-250.

${ }^{6}$ For a detailed discussion of these issues see, inter alia, Daragh Murray (ed), Practitioners' Guide to Human Rights Law in Armed Conflict (OUP 2016) especially chapters 9, 12, and 17.

7 ICTY, Prosecutor v Kupreškić et al (Judgement) Case No IT-95-16-T (14 January 2000) paras 518 and 525 (hereafter Kupreškić Trial Judgment). 


\section{Substantive Convergence between Human Rights and Humanitarian Law: Human Dignity}

The increasing interaction between IHRL and IHL and their substantive convergence are the result of a gradual process, which has been taking place both at a conceptual and at an institutional level. Conceptually, such convergence rests on shared core values, including the protection of human life, human dignity, and bodily integrity, as well as avoiding or reducing material damage to public and private property. At an institutional level, this convergence is driven by the concurrent use of both human rights and humanitarian law in the practice of international and regional organizations and judicial and quasi-judicial bodies. ${ }^{8}$ Although admittedly such application does not occur in a systematic manner, Article 31(3)(c) of the 1969 Vienna Convention on the Law of Treaties (VCLT), requiring for a treaty to be interpreted in harmony with other applicable rules of international law, provides a legal basis for such an effort. Arguably, then, the concurrent use of IHRL and IHL should be more prominent and visible in the work of international fact-finding commissions and the UN Human Rights Council. Simultaneously, the difficulties of such systemic integration are more pronounced in the case law of international courts and regional human rights courts, largely due to jurisdictional gaps, but also because of differences between these branches of public international law.

The ICJ has identified three possible situations concerning the relationship between international human rights and humanitarian law, namely some rights may exclusively be matters of international humanitarian law; others may exclusively be matters of human rights law; yet others may be matters of both these branches of international law. ${ }^{9}$ The ICTY has noted that ' $[$ t]he laws of war do not necessarily displace the laws regulating a peacetime situation; the former may add elements requisite to the protection which needs to be afforded to victims in a wartime situation'. ${ }^{10}$ Moreover, the ICTY has emphasized that with regard to certain of its aspects, international humanitarian law can be said to have fused with human rights law. ${ }^{11}$ The ECtHR has found that even in situations of international armed conflict, the safeguards under the ECHR

8 See among others UNGA Res 2444 (XXIII) of 1968, 3500 (XXX) of 1975; UNSC Res (1995) UN Doc S/RES/1034, (2004) UN Doc S/RES/1565, (2006) UN Doc S/RES/1738, (2015) S/RES/2225; Human Rights Council Res 5/1 (2007), Human Rights Council Res 9/9 (2008); CCPR General Comment 29 ('States of Emergency: Article 4', paras 3, 9, 11, and 16) and General Comment 31 ('Nature of the General Legal Obligation Imposed on States Parties to the Covenant', para 11); Parliamentary Assembly of the Council of Europe Recommendation 1427 (1999) and Res 2133 (2016), see also $<$ www.coe.int/en/web/cahdi/humanitarian-international-law-theme>; Updated European Union Guidelines on promoting compliance with international humanitarian law (IHL), 2009/C 303/06.

${ }^{9}$ Legal consequences of the construction of a wall in the occupied Palestinian territory (Advisory Opinion) [2004] ICJ Rep 178, para 106 (hereafter Wall Advisory Opinion). See also Armed activities on the territory of the Congo (Democratic Republic of the Congo v Uganda) (Judgment) [2005] ICJ Rep 242-243, para 216 (hereafter Armed Activities case).

10 See ICTY, Prosecutor v Dragoljub Kunarac, Radomir Kovač and Zoran Vuković (Appeals Chamber Judgement) Case No IT-96-23\& IT-96-23/1 A (12 June 2002) para 60 (hereafter Kunarac Appeals Judgment).

11 Prosecutor v Kunarac et al., ICTY-96-23-T \& ICTY-96/23/1-T, Trial Judgment (22 February 2001) (Kunarac Trial Judgment) para 467. 
continue to apply, albeit interpreted against the background of the provisions of international humanitarian law. ${ }^{12}$ These broad legal findings support a model of interaction between IHRL and IHL that can be applied to multinational military operations, those with 'active hostilities' where IHL provides the primary legal framework, and the 'security operations' where IHRL provides the primary legal framework. ${ }^{13}$ Looking at this relationship from a holistic perspective, Bethlehem has argued that the interaction between human rights and humanitarian law could take six different forms, including (1) IHRL acting as a gateway for the application of IHL by way of renvoi; (2) IHRL giving effect to a relevant but otherwise inapplicable provision of IHL; (3) IHRL informing the interpretation of IHL, including possibly by supplementing or completing the IHL rule; (4) IHRL prevailing over inconsistent IHL; (5) IHRL filling in the gaps in circumstances in which there is no relevant IHL provision; and (6) IHRL augmenting $\mathrm{IHL}$ through $\mathrm{HRL}$ procedural and accountability mechanisms. ${ }^{14}$ These six different scenarios highlight the complex interaction between these bodies of law and the difficult choices that the ECtHR has to make when deciding cases.

The concept of human dignity occupies an important place in both international human rights law and international humanitarian law, centring on the inherent worth of respecting and protecting every human being. ${ }^{15}$ As the International Criminal Tribunal for the Former Yugoslavia (ICTY) has stated,

'The essence of the whole corpus of international humanitarian law as well as human rights law lies in the protection of the human dignity of every person, whatever his or her gender. The general principle of respect for human dignity is the basic underpinning and indeed the very raison d'être of international humanitarian law and human rights law; indeed in modern times it has become of such paramount importance as to permeate the whole body of international law. This principle is intended to shield human beings from outrages upon their personal dignity, whether such outrages are carried out by unlawfully attacking the body or by humiliating and debasing the honour, the self-respect or the mental well being of a person'. ${ }^{16}$

12 Hassan v United Kingdom App no 29750/09 (ECtHR, Grand Chamber Judgment, 16 September 2014) para 104.

13 Daragh Murray (ed), Practitioners' Guide to Human Rights Law in Armed Conflict (OUP 2016) 88-108, especially 90-92.

${ }^{14}$ Bethlehem, 'The relationship between international humanitarian law and international human rights law' (n 1) 195.

15 See inter alia Christopher McCrudden, 'Human Dignity and Judicial Interpretation of Human Rights' [2008] 19(4) EJIL 655-724; Aharon Barak, Human Dignity: The Constitutional Value and the Constitutional Right (Cambridge University Press 2015) especially at 34-48.

${ }_{16}$ ICTY, Prosecutor v Furundžija (Judgment) Case No IT-95-17/1-T (10 December 1998) para 183. See also para 162 of this judgment where the ICTY states that the primary purpose of this body of law [IHL] is to safeguard human dignity. 
Several international human rights treaties and other relevant instruments make reference to human dignity. ${ }^{17}$ The same goes for international humanitarian law treaties. ${ }^{18}$ First, at a general level, this concept covers the protection of persons against acts which go against their personal dignity, both in peacetime and in times of armed conflict. Second, the commission of crimes against humanity and the most serious violations of the laws and customs of war is considered a serious infraction of human dignity. ${ }^{19}$ Third, the dignity of victims and witnesses is also

17 See among others preamble, Articles 1, 22 and 23, of the 1948 Universal Declaration on Human Rights, UNGA Res 217 A (III), UN Doc A/810 at 71; preamble to the 1965 International Convention on the Elimination of All Forms of Racial Discrimination (adopted 21 December 1965, entered into force 4 January 1969) United Nations, Treaty Series, vol 660, 195; preamble, article 10 of the 1966 International Covenant on Civil and Political Rights (adopted 16 December 1966, entered into force 23 March 1976) United Nations, Treaty Series, vol 999, 171 (hereafter ICCPR); preamble, Article 13 of the 1966 International Covenant on Economic, Social and Cultural Rights (adopted 16 December 1966, entered into force 3 January 1976) United Nations, Treaty Series, vol 993, 3; preamble to the 1979 Convention on the Elimination of All Forms of Discrimination against Women (adopted 18 December 1979, entered into force 3 September 1981) United Nations, Treaty Series, vol 1249, 13; preamble to the 1984 Convention against Torture and Other Cruel, Inhuman or Degrading Treatment or Punishment (adopted 10 December 1984, entered into force 26 June 1987) United Nations, Treaty Series, vol 1465, 85; preamble, articles 23(1), 28(2), 37(c), 39, and 40(1) of the 1989 Convention on the Rights of the Child (adopted 20 November 1989, entered into force 2 September 1990) United Nations, Treaty Series, vol 1577, 3; articles 17(1) and 70 of the 1990 International Convention on the Protection of the Rights of All Migrant Workers and Members of Their Families (adopted 18 December 1990, entered into force 1 July 2003) United Nations, Treaty Series, vol 2220, 3; preamble, articles 1, 3, 8(1)(a), 16(4), 24(1)(a), and 25(d) of the 2006 Convention on the Rights of Persons with Disabilities (adopted 13 December 2006, entered into force 3 May 2008) United Nations, Treaty Series, vol 2515, 3; articles 19(2) and 24(5)(c) of the 2006 International Convention for the Protection of all Persons from Enforced Disappearance (adopted 20 December 2006, entered into force 23 December 2010) United Nations, Treaty Series, vol 2716, 3. See also the preamble to Protocol 13 to the ECHR (adopted 3 May 2002, entered into force 1 July 2003) ETS No 187, concerning the abolition of the death penalty in all circumstances.

${ }^{18}$ See Article 3(1)(c) Common to the Four Geneva Conventions of 1949, namely the Geneva Convention for the Amelioration of the Condition of the Wounded and Sick in Armed Forces in the Field (First Geneva Convention) (adopted 12 August 1949, entered into force 21 October 1950) 75 UNTS 31 (hereafter GC I), the Geneva Convention for the Amelioration of the Condition of Wounded, Sick and Shipwrecked Members of Armed Forces at Sea (Second Geneva Convention) (adopted 12 August 1949, entered into force 21 October 1950) (hereafter GC II), the Geneva Convention Relative to the Treatment of Prisoners of War (Third Geneva Convention) (adopted 12 August 1949, entered into force 21 October 1950) 75 UNTS 135 (hereafter GC III), the Geneva Convention Relative to the Protection of Civilian Persons in Time of War (Fourth Geneva Convention) (adopted 12 August 1949, entered into force 21 October 1950) 75 UNTS 287 (hereafter GC IV); Articles 75(2)(b) and 85(4)(c) of the Protocol Additional to the Geneva Conventions of 12 August 1949, and Relating to the Protection of Victims of International Armed Conflicts (Protocol I) (adopted 8 June 1977, entered into force 7 December 1978) 1125 UNTS 3 (hereafter AP I); Article 4(2)(e) of the Protocol Additional to the Geneva Conventions of 12 August 1949, and relating to the Protection of Victims of Non-International Armed Conflicts (Protocol II) (adopted 8 June 1977, entered into force 7 December 1978) 1125 UNTS 609 (hereafter AP II); preamble to European Convention on the NonApplicability of Statutory Limitations to Crimes against Humanity and War Crimes (adopted 25 January 1974, entered into force 27 June 2003) ETS No 082; preamble to the Convention on Cluster Munitions (adopted 30 May 2008, entered into force 1 August 2010) United Nations, Treaty Series, vol 2688, 39.

${ }^{19}$ See inter alia Article 3 of the Statute of the Special Court for Sierra Leone, adopted by UNSC Res 1315 (2000) UN Doc S/RES/1315 (hereafter SCSLSt), Article 4(e) of the Statute of the International Criminal Tribunal for the Prosecution of Persons Responsible for Genocide and Other Serious Violations of International Humanitarian Law Committed in the Territory of Rwanda and Rwandan Citizens Responsible for Genocide and Other Such Violations Committed in the Territory of Neighbouring States, 
safeguarded during the criminal legal process. ${ }^{20}$ And fourth, particular attention has also been paid to child soldiers between 15 and 18 years of age, with a view to their rehabilitation. ${ }^{21}$ Together, these different aspects of the concept of dignity lay down broad standards of conduct relevant for both states and non-state actors in situations of armed conflict.

\section{Substantive Convergence Concerning Protection of Civilians in Armed Conflict}

Article 15 of the ECHR allows for derogations 'in time of war or other public emergency threatening the life of the nation'. No derogations can be made to Article 2 on the right to life though, 'except in respect of deaths resulting from lawful acts of war'. Many cases relating to armed conflicts have been brought before the ECtHR, including the Turkey-Cyprus and TurkeyPKK conflict, Armenian-Azerbaijani conflict over Nagorno-Karabakh, the 1990s armed conflicts in the Balkans, Chechnya, Georgia, and Ukraine. ${ }^{22}$ Challenges remain in reconciling the rules of international humanitarian law with the rules of European human rights law. ${ }^{23}$ The EU's involvement in armed conflicts is closer to the 'security operations', where IHRL provides the primary framework. ${ }^{24}$ This section addresses two issues, namely protection of the right to life under Article 2, and detention and the protection of personal liberty under Article 5 of the ECHR.

\subsection{Protection of the right to life in armed conflict}

The approach to the right to life is where the difference between human rights and humanitarian law, and 'security operations' and 'active hostilities' paradigms, respectively, comes most to the fore. The arbitrary taking of life is prohibited under both human rights ${ }^{25}$ and

between 1 January 1994 and 31 December 1994, adopted by UNSC Res 955 (1994) UN Doc S/RES/955, amended by UNSC Res 1165 (1998) UN Doc S/RES/1165, 1329 (2000) UN Doc S/RES/1329, 1411 (2002) UN Doc S/RES/1411 and 1431 (2002) UN Doc S/RES/1431 (hereafter ICTRSt), Article 8 of the Rome Statute of the International Criminal Court (adopted 17 July 1989, entered into force 1 July 2002) United Nations, Treaty Series, vol 2187, 3 (hereafter ICCSt). These articles criminalize outrages upon personal dignity, in particular humiliating and degrading treatment, rape, enforced prostitution and any form of indecent assault.

20 ICCSt., Article 68, 'Protection of the victims and witnesses and their participation in the proceedings'.

${ }^{21}$ SCSLSt., Article 7(1), 'Jurisdiction over Persons of 15 Years of Age'.

22 For a general overview of relevant cases see the ECtHR factsheet on 'Armed Conflicts', at

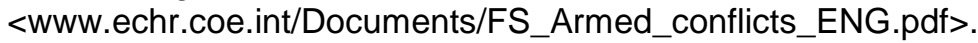

${ }^{23}$ See among others Claire Landais and Léa Bass, 'Reconciling the rules of international humanitarian law with the rules of European human rights law' [2015] 97 IRRC 1295-1311.

24 See among others Frederik Naert, The Application of International Humanitarian Law and Human Rights Law in CSDP Operations (Brill 2011); Gentian Zyberi, 'The Applicability of General Principles and Instruments of International Law to Peace Missions of the European Union' in Aurel Sari and Ramses A. Wessel (eds), Human Rights in EU Crisis Management Operations: A Duty to Respect and to Protect? (CLEER Working Paper Series 2012/6) 21-37; Frederik Naert, 'Observance of international humanitarian law by forces under the command of the European Union' [2013] 95 IRRC 637-643.

${ }^{25}$ Article 6(1) ICCPR; Article 2(2) of the European Convention for the Protection of Human Rights and Fundamental Freedoms (adopted 4 November 1950, entered into force 3 September 1953) ETS No 5 (hereafter ECHR); Article 4(1) of the American Convention on Human Rights (adopted 22 November 1969, entered into force 18 July 1978) available at <http://www.refworld.org/docid/3ae6b36510.html> (hereafter 
humanitarian law ${ }^{26}$. When it comes to active hostilities, what is arbitrary is specifically regulated under international humanitarian law, as the ICJ has emphasized. ${ }^{27}$ Following a similar line of reasoning, in its November 2015 General Comment 3 on the right to life, the African Commission on Human and Peoples' Rights (African Commission) has stated that,

'[t]he right to life continues to apply during armed conflict. During the conduct of hostilities, the right to life needs to be interpreted with reference to the rules of international humanitarian law. In all other situations the intentional deprivation of life is prohibited unless strictly unavoidable to protect another life or other lives' ${ }^{28}$

Doswald-Beck has argued that the human rights law relating to the right to life is suitable to supplement and interpret IHL rules relating to the use of force for non-international conflicts and occupation, as well as the law relating to civilians taking a 'direct part in hostilities'. ${ }^{29}$ Tomuschat goes one step further by arguing that cases of the use of force outside active hostilities should all be reviewed on the basis of human rights - exclusively according to human rights. ${ }^{30}$ Oberleitner seems to provide a more nuanced approach to the 'capture or kill' debate, by arguing that the idea of a human rights-based approach to the use of force should not be ruled out as a matter of principle, but that it is rather about analysing its feasibility under operational, tactical, and resource constraints in order to find out when it is legally sound and realistically applicable. ${ }^{31}$ Schabas has added another important if controversial element to this discussion by arguing that killing that results from resort to illegal war and acts of aggression is prima facie a violation of the human right to life. ${ }^{32}$ It is doubtful whether the ECtHR will explicitly address the issue of lawfulness of resorting to armed force.

ACHR); Article 4 of the African Charter on Human and Peoples' Rights (adopted 27 June 1981, entered into force 21 October 1986) CAB/LEG/67/3 rev 5, 21 ILM 58 (hereafter ACHPR). See also Principles on the Effective Prevention and Investigation of Extra-Legal, Arbitrary and Summary Executions, UN ESCOC Res 1989/65 (1989) UN Doc E/RES/1989/65, annex; Supp (No 1) (1989) UN Doc E/1989/89, at 52.

${ }^{26}$ Common Article 3 to the four Geneva Conventions. The prohibition on killing civilians and persons hors de combat is also included in many military manuals. See also Rule 89 of the CIHL Study on 'Violence to Life' at <https://ihl-databases.icrc.org/customary-ihl/eng/docs/v1_rul_rule89>.

${ }^{27}$ Legality of the threat or use of nuclear weapons (Advisory Opinion) [1996] ICJ Reports 240, para 25 (Nuclear Weapons Advisory Opinion).

28 African Commission on Human and Peoples' Rights, 'General Comment No. 3 on the African Charter on Human and Peoples' Rights: The Right to Life (Article 4)' (November 2015) para 13; at $<$ www.achpr.org/instruments/general-comments-right-to-life>.

29 Louise Doswald-Beck, 'The right to life in armed conflict: does international humanitarian law provide all the answers?' [2006] 88 IRRC 903-904; Vera Gowlland-Debbas, 'Harmonising the Individual Protection Regime: Some Reflections on the Relationship between Human Rights and International Humanitarian Law in the Light of the Right to Life' in Aristotle Constantinides and Nikos Zaikos (eds), The Diversity of International Law: Essays in Honour of Professor Kalliopi K. Koufa (Brill 2009) 399-418.

${ }^{30}$ Christian Tomuschat, 'Human Rights and International Humanitarian Law' [2010] 21(1) EJIL at 22.

${ }^{31}$ Gerd Oberleitner, Human Rights in Armed Conflict: Law, Practice, Policy (Cambridge University Press 2015) 131-143, at 140.

32 William Schabas, 'Right to Life' in Andrew Clapham and Paola Gaeta (eds), The Oxford Handbook of International Law in Armed Conflict (OUP 2014) 385. 
The issue of respect for the right to life in multinational operations has been raised in several cases, involving military operations under UN mandate in Kosovo (UNMIK) ${ }^{33}$ and in Afghanistan (ISAF), ${ }^{34}$ as well as multinational military operations in Iraq. ${ }^{35}$ For alleged violations of the right to life in situations where military personnel were operating under a UN mandate, the ECtHR has invoked the immunity of the UN before domestic courts and has dismissed the cases. ${ }^{36} \mathrm{~A}$ similar reasoning was adopted for cases relating to NATO operations in the former Yugoslavia. ${ }^{37}$ Such immunity does not seem to be a problem in multinational military operations not undertaken under the umbrella of an international or regional organization. Thus, in deciding whether the transfer by the British authorities into Iraqi custody put two Iraqi nationals at real risk of execution by hanging, in violation of Article 2 or Article 1 of Protocol No. 13, as regards the latter the ECtHR took the view that 'in respect of those States which [were] bound by it, the right under Article 1 of Protocol No. 13 not to be subjected to the death penalty, which admit[ted] of no derogation and applie[d] in all circumstances, rank[ed] along with the rights in Articles 2 and 3 as a fundamental right, enshrining one of the basic values of the democratic societies making up the Council of Europe'. ${ }^{38}$ This would mean that unless guarantees are given that the person will not be subjected to the death penalty, European states that are a party to Protocol 13 cannot transfer a person to the custody of another state that applies the death penalty. While the ECtHR still has to develop its case law on Article 2 in relation to multinational military operations, it is foreseeable that its use of IHL vocabulary such as 'incidental loss of human life', 'choice of means and methods', 'disproportionality in the weapons used', and resort to the fundamental principles of IHL, namely distinction, proportionality, and precautions in attack, ${ }^{39}$ could potentially bridge the gap between IHL and IHRL.

\subsection{Detention and the protection of the right to liberty}

Perhaps the clearest shift and trend towards convergence between IHL and human rights in the European legal context relates to substantive and procedural norms governing detention. For European States, the treaty text of the ECHR on the right to liberty and security of person appeared for a long time to be hard to reconcile with the rules on internment in the Geneva Conventions III and IV, resulting in ambiguity concerning the lawfulness of detention connected to armed conflicts. Recent years have brought about a significant change in this regard, with

${ }^{33}$ Behrami and Behrami v France App no 71412/01 (ECtHR Grand Chamber Decision on Admissibility, 2 May 2007).

34 Hanan v Germany (no 4871/16), pending application.

35 See Al-Saadoon and Mufdhi $v$ the United Kingdom App no 61498/08 (ECtHR, 2 March 2010); Al-Skeini and Others v UK App no 55721/07 (ECtHR Grand Chamber Judgement, 7 July 2011) (hereafter Al-Skeini v UK); Hassan v The UK App no 29750/09 (ECtHR Grand Chamber Judgment, 16 September 2014); Jaloud $v$ Netherlands App no 47708/08 (ECtHR Grand Chamber Judgement, 20 November 2014).

${ }^{36}$ Behrami and Behrami v France App no 71412/01 (ECtHR Grand Chamber Decision on Admissibility, 2 May 2007). See also Stichting Mothers of Srebrenica and Others $v$ the Netherlands App no 65542/12 (ECtHR, 11 June 2013).

${ }^{37}$ See Banković and Others v Belgium and 16 Other Contracting States App no 52207/99 (ECtHR Grand Chamber Decision as to the admissibility, 12 December 2001); Markovic and Others $v$ Italy App no 1398/03 (ECtHR Grand Chamber Judgement, 14 December 2016).

${ }^{38}$ Al-Saadoon and Mufdhi $v$ the United Kingdom App no 61498/08 (ECtHR, 2 March 2010) para 118.

39 Oellers-Frahm (n 5) 350. 
substantive convergence of the ECHR and IHL relating to IACs. Yet questions remain as to whether this tendency is equally relevant for detention in NIAC. This part will examine the developments concerning the fundamental issue of lawfulness of detention in IAC and NIAC. ${ }^{40}$

Detention is a severe control measure, which involves a serious restriction of a person's liberty but also constitutes an important tool in military operations authorized to use force, whether as part of counter-terrorism, counter-insurgency, an armed conflict or occupation, or in the context of a peace operation mandated to employ forceful measures. ${ }^{41}$ The legal issues related to security internment or administrative detention constitute some of the most complex legal challenges in multinational military operations. ${ }^{42}$ Both $\mathrm{IHL}$ and IHRL prohibit arbitrary detention. ${ }^{43}$ Yet there is controversy as to how to assess what is arbitrary in situations where both areas of law apply. The ambiguity involves the overall relationship between IHL and IHRL and is further complicated by differences in treaty provisions concerning IACs and NIACs, and that IHRL instruments provide different texts on the right to liberty. As Oswald has held, the failure to 'settle on the precise relationship between $\mathrm{IHL}$ and IHRL means that states will continue to determine their interpretation of applicable law on a case-by-case basis'. ${ }^{4}$

As regards internment in IACs, IHL contains specific rules on basis, treatment, and procedures. Geneva Convention III authorizes and regulates the internment of POW; here, necessity for internment is implied based on the function of a combatant. ${ }^{45}$ Geneva Convention IV authorizes the internment of civilians (protected persons) when it is 'absolutely necessary' (on own territory) or warranted for 'reasons of imperative security' (on occupied territory), coupled with rules on procedures and the end of such internment. ${ }^{46}$ This stands in contrast to the more narrow regulation for NIACs. While IHL regulates treatment of persons deprived of liberty, conditions of detention, and criminal procedure and punishment in NIACs, it provides no explicit authorization or ground for security internment in NIAC, or procedural requirements that are comparable to

${ }^{40}$ Other detention-related challenges include treatment, conditions of detention facilities, transfer and handover of detainees (e.g. between troop contributing States and to the host-State) but these will not be dealt with in this chapter.

41 Bruce Oswald, 'Interplay as regards dealing with detainees in international military operations' in Erika de Wet and Jann K. Kleffner (eds), Convergence and Conflicts of Human Rights and International Humanitarian Law in Military Operations (Pretoria University Law Press (hereafter PULP) 2014) 69. See also (iii) in the preamble of the Copenhagen Principles and Guidelines on the Handling of Detainees in International Military Operations, welcomed 19 October 2012, available via <http://um.dk/>.

42 Bruce Oswald, 'Some controversies of detention in multinational operations and the contributions of the Copenhagen Principles' [2013] 95 IRRC 707, 711.

${ }^{43}$ Article 9 ICCPR, article 5 ECHR, and rule 99 ICRC, Customary International Humanitarian Law Database on Rules and Practice (ICRC based on the 2005 Cambridge University Press publication, continuously updated) (ICRC CIHL Study) stating that arbitrary detention is prohibited in both IAC and NIAC. See also Copenhagen Principles.

44 Oswald, 'Some controversies of detention in multinational operations and the contributions of the Copenhagen Principles' [2013] 95 IRRC 707, 723.

45 Articles 4 (definition of a POW), 5 (procedure in case of doubt), 21 (basis for internment) and 118-119 (repatriation) GC III.

${ }^{46}$ Articles 4 (defines protected persons), 27.4 (basis for internment of civilians when grounds are met), 4142 (basis for internment in own territory), 43 (procedure), and 78 (basis for internment in occupied territory) and 132 (end of internment) GC IV; see also article 75 AP I. 
those in GC III and IV applicable in IACs. ${ }^{47}$ States and the ICRC generally consider that IHL, with the regime briefly described above, provides a sufficient legal basis for detention in IACs, even in the absence of relevant domestic law. ${ }^{48}$ The issue is less clear concerning NIACs. Some scholars argue that IHL applicable in NIACs contains an implicit legal basis for detention. ${ }^{49}$ The ICRC has formulated it as IHL contains an 'inherent power to intern' which is sufficient to serve as a legal basis for detention in NIAC. ${ }^{50}$ Others argue that a basis for detention must not be implicit but explicit, and that therefore detention in NIACs has no legal basis in IHL, but must be established in domestic law (or, possibly, UNSC resolutions). ${ }^{51}$

The ECtHR has found that restriction of the right to liberty must be established by law, the ground for detention must be legitimate, and adequate procedures must be in place and respected in order to be lawful under Article $5 \mathrm{ECHR} .{ }^{52}$ The Court has provided that while the requirement for 'law' in the meaning of providing a legal basis for deprivation of liberty most commonly refers to domestic legislation, ${ }^{53}$ international law may constitute 'law' in this sense if it is clearly defined and foreseeable. ${ }^{54}$ Multinational military operations may of course detain under domestic law, but there may also be reason to base detention on international law - especially IHL. The issue is particularly complex in NIACs as it is questionable if IHL in NIACs would be considered as providing (sufficiently clear) authorization and regulation of detention. While IHL in IACs contains clearly defined rules for internment and should be deemed foreseeable, it does give rise to challenges concerning grounds and procedure as required under Article 5 ECHR.

As regards 'grounds', the ECHR is special in comparison to Article 9(1) of the ICCPR, since Article 5(1)(a)-(f) ECHR set out an exhaustive list of legitimate grounds for detention - none of which mentions internment or administrative detention. The ECtHR has continuously held that

${ }^{47}$ See article 3 GC I-IV and articles 5-6 AP II.

48 This view was e.g. expressed by several States in the initial phases of the Copenhagen Process, see Oswald, 'Some controversies of detention in multinational operations and the contributions of the Copenhagen Principles' [2013] 95 IRRC 707, 721. See also ICRC, 'Internment in Armed Conflict: Basic Rules and Challenges, Opinion Paper' (November 2014) avilable at $<$ https://www.icrc.org/en/document/internment-armed-conflict-basic-rules-and-challenges> 4-6. Note that ICRC mentions that this position has sometimes been challenged concerning internment of civilians, 5 .

49 For example, Sandesh Sivakumaran, The Law of Non-International Armed Conflict (OUP 2012) 301, Sean Aughey and Aurel Sari, 'Targeting and Detention in Non-International Armed Conflict: Serdar Mohammed and the Limits of Human Rights Convergence' [2015] 91 International Law Studies 60, 116. See also Daragh Murray, Examining Detention Authority in NIAC: A Response to Heller (Opinio Juris 2017). 50 ICRC, 'Internment in Armed Conflict: Basic Rules and Challenges, Opinion Paper' (November 2014) avilable at <https://www.icrc.org/en/document/internment-armed-conflict-basic-rules-and-challenges $>7$.

51 For example, Lawrence Hill-Cawthorne, Detention in Non-International Armed Conflict (OUP 2016) 75. See also Kevin Jon Heller, IHL Does Not Authorise Detention in NIAC: A Response to Murray (Opinio Juris 2017).

52 Louise Doswald-Beck, Human Rights in Times of Conflict and Terrorism (OUP 2011) 253.

${ }^{53}$ Saadi $v$ the United Kindgom App no 13229/03 (ECtHR Grand Chamber Judgment, 29 January 2008) para 67.

54 Medvedyev and others v France App no 3394/03 (ECtHR Grand Chamber Judgment, 29 March 2010) (hereafter Medvedyev $v$ France) para 80 and 99-100 (in this case a diplomatic note authorizing certain measures was seen as legally binding between the two relevant states but did not meet the criteria of clarity and foreseeability to suffice as law restricting the right to liberty and security of person). 
Article 5 only allows for a narrow interpretation, ${ }^{55}$ and that Article 5(1)(c) ECHR does not allow for detention if there is no intent to bring criminal charges within a reasonable timeframe. ${ }^{56}$ Detention not based on one of the grounds in Article 5(1)(a)-(f) is in violation of the ECHR, which in effect means that security internment or administrative detention is unlawful in normal circumstances.

Article $5 \mathrm{ECHR}$ is derogable, however, and based on a valid derogation under Article 15, a state party could take measures that would otherwise depart from the Convention, for example to establish a temporary ground for administrative detention. ${ }^{57}$ Derogating measures must be restricted to what is strictly required by the exigencies of the situation and must not be unjustifiably discriminatory. ${ }^{58}$ Whether derogations related to situations outside the state party's territory (which is relevant in multinational military operations) are permitted under the ECHR is still unclear. ${ }^{59}$ Based on the ECtHR's findings in Hassan v. the United Kingdom (see below), this is unnecessary for internment under IHL in IACs, and thus likely only to be relevant in NIACs and emergency situations falling short of an armed conflict.

The issue of security internment based on UNSC resolution and its relation to ECHR was raised in Al Jedda $v$. the United Kingdom. Al Jedda $v$. UK concerned internment for imperative reasons of security (partly) during an occupation, but the case was primarily focused on the relationship between a UNSC resolution and the ECHR. The primary reason for such focus was that the UK had argued that the internment was based on UNSC resolution 1546 (2004), ${ }^{60}$ which the UK claimed 'created an obligation on the United Kingdom to detain the applicant which, pursuant to Article 103 of the Charter of the United Nations, overrode obligations under the Convention'. ${ }^{61}$ The Court found that the broad authorization (to use all necessary means) in resolution 1546 did not create an 'obligation' upon the UK to subject $A$ / Jedda to indefinite security internment. ${ }^{62}$ Further, the ECtHR held that internment under IHL in occupation 'is to be viewed not as an obligation on the Occupying Power but as a measure of last resort'. ${ }^{63}$ Accordingly, the

55 Engel and Others $v$ the Netherlands App no 5100/71; 5101/71; 5102/71; 5354/72; 5370/72 (ECtHR, 8 June 1976) para 58, Medvedyev v France (n 54).

56 Lawless v Ireland (no. 3) App no 332/57 (ECtHR, 1 July 1961) para 13-14, Ireland $v$ United Kingdom App no 5310/71 (ECtHR, 18 January 1978) para 196, Guzzardi v Italy App no 7367/76 (ECtHR, 6 November 1980) para 102, Jéčius $v$ Lithuania App no 34578/97 (ECtHR, 31 July 2000) para 47-52, and Al Jedda $v$ the United Kingdom App no 27021/08 (ECtHR Grand Chamber Judgement, 7 July 2011) (hereafter Al Jedda $v$ the United Kingdom) para 100 and 110. Note also Hassan $v$ The UK App no 29750/09 (ECtHR Grand Chamber Judgment, 16 September 2014).

57 See article 15 ECHR and Al Jedda $v$ the United Kingdom ( $\mathrm{n} 56$ ).

${ }^{58}$ Article 15.1 and $A$ and others $v$ the United Kingdom (ECtHR) para 172 and 190.

59 The Court avoided the issue in Hassan $v$ UK, which concerned a situation in Iraq, but pointed out that no derogation was made, which could be read as an indication that it is possible. Hassan $v$ The UK App no 29750/09 (ECtHR Grand Chamber Judgment, 16 September 2014). For a detailed analysis of the issues pertaining to of extra-territorial derogations, see Marko Milanovic, 'Extraterritorial Derogations from Human Rights Treaties in Armed Conflict' in Nehal Bhuta (ed), The Frontiers of Human Rights (OUP 2016).

60 UNSC Res 1546 (8 June 2004) UN Doc S/RES/1546, adopted by the Security Council at its 4987th meeting.

${ }^{61}$ Al Jedda $v$ the United Kingdom (n 56).

62 Ibid.

63 Ibid. 
Court concluded that there was no obligation under the Charter of the United Nations ${ }^{64}$ that was in conflict with (and could have replaced) the obligations under Article $5 \mathrm{ECHR}$. Thus, the internment - which did not comply with Article 5 - was deemed unlawful. ${ }^{65}$

The issue of whether security internment based on GC III and GC IV may be compatible with Article 5 ECHR was raised in Hassan v. UK. This case, decided in 2014, was the first where a responding government argued that the Court should displace or interpret Article $5 \mathrm{ECHR}$ in light of IHL. Given previous case law, the point of departure in Hassan was that Article 5 ECHR normally - excludes internment and administrative detention. The Court also held that the internment regime of GC III and IV is prima facie inconsistent with the grounds set out in Article 5(1)(a)-(f). ${ }^{66}$ However, the Court then turned to the particularities of armed conflicts and $\mathrm{IHL}$ and recognized the significant differences in context and purpose between detention in peacetime and internment under IHL during an armed conflict. ${ }^{67}$ Further, the Court held that it was to take into account, for instance, subsequent practice and IHL when interpreting the ECHR. Notably, the Court also held that subsequent practice could not only inform the interpretation, but also modify the provisions of the ECHR. ${ }^{68}$ Importantly, it also emphasized that Article 5 ECHR (as Article 2) should be interpreted in light of IHL as far as is possible. ${ }^{69}$ It accordingly applied Article 5 ECHR in light of the regulation in GC III and IV and effectively added to Article 5 ECHR the additional grounds and modified the procedures as provided for in GC III and IV in IACs concluding that there had been no violation. Hence, security internment of POW and civilians is acceptable under Article 5 during IACs, when it conforms to the relevant rules of IHL. ${ }^{70}$ The extent to which the Court included IHL into its interpretation of Article 5 ECHR in Hassan constitutes a novelty. While the Court did not develop a general theory on the relationship of IHL and the ECHR, it emphasized its role in interpreting the ECHR in line with other relevant rules of international law in a manner which potentially contributes to a better working relationship between IHL and the $\mathrm{ECHR}$. The result of this pragmatic interpretation is substantive convergence which fits with the general understanding of states and the ICRC of detention under IHL in IACs.

After Hassan, much of the remaining controversies regarding the relationship between IHL and IHRL in regard to detention concerns NIAC; here, the trend of convergence may meet other difficulties - the ambiguity over whether IHL provides a basis for detention at all. The relationship between IHL and IHRL concerning detention in multinational military operations in NIACs (and peace operations) was subject to discussions during the Copenhagen Process. ${ }^{71}$ Ultimately, IHRL

${ }^{64}$ Charter of the United Nations (adopted 26 June 1945, entered into force 24 October 1945) 1 UNTS XVI (hereafter UN Charter).

${ }^{65}$ Al Jedda $v$ the United Kingdom (n 56).

${ }^{66}$ Hassan $v$ The UK App no 29750/09 (ECtHR Grand Chamber Judgment, 16 September 2014).

67 Ibid.

$68 \mathrm{lbid}$. Note also the dissenting opinion criticising the majority's finding in this regard.

69 Ibid para 102.

70 lbid para 104-106.

71 The Danish government initiated the so-called Copenhagen Process in 2007. It consisted of a series of meetings for (some) states, international organisations and representatives of civil society on the topic of detention in multinational military operations and resulted in the Copenhagen Principles, "welcomed" in 2012. 
was merely mentioned in the preamble of the non-legally binding Copenhagen Principles, and not given a prevalent role in the principles. ${ }^{72}$ Oswald has noted that it would therefore seem that those participating in the Process had no difficulties in accepting the application of both IHL and IHRL - the problem rested on agreeing on the precise interaction between the two bodies of law. ${ }^{73}$ The ECtHR has accepted customary international law as legal basis for serving a prison sentence under Article 5(1)(a) ECHR. However, this customary rule was supported by related domestic regulation - and, notably, the ground was clearly within Article $5 .{ }^{74}$ Given how the Court has emphasized the context of an IAC and the particularities of the detailed regulation of internment IHL in IACs (which exist in treaty and $\mathrm{CIHL}$ ) in Hassan while simultaneously upholding the prohibition on such detention in peacetime, and taking into account the difference in regard to the practice of detention, the Court might find it more challenging to modify Article 5(1) and 5(4) ECHR in NIACs in a similar way as it did in Hassan.

In conclusion, with the Hassan judgment, the ECtHR provided clarification to important aspects of the legal challenges relating to detention in IACs and took the convergence of the relevant norms in IHL and ECHR a significant step further. The clear focus on IACs though means that questions relating to detention in NIACs remain and the controversies over IHL in NIACs implicate that a similar approach to that in Hassan is unlikely. Thus, in relation to detention in IACs there is clear substantive convergence in the European perspective, but there are seemingly obstacles to a similar convergence in NIACs. As regards UNSC resolutions as a basis for detention, the normal formulation of authorizing 'all means necessary' does not absolve a state party of its obligations under Article 5 ECHR - but a clearly expressed obligation to detain likely would, based on Article 103 UN Charter. Hence, ECHR state parties in multinational military operations engaged in NIACs or situations falling short of armed conflicts would need to derogate in order to use a detention regime based on other grounds or procedures than those provided for in Article 5(1)-(4) ECHR.

\section{The Right to Humanitarian Assistance}

The number of persons fleeing from conflicts and in need of humanitarian assistance and protection has increased considerably over the last decade. Amongst the most severe, largescale humanitarian crises are those occurring in Iraq, Syria, and Yemen. ${ }^{75}$ The EU - member states and EU institutions collectively - is among the leading donors of humanitarian aid in the

\footnotetext{
72 Preamble. This is one of the reasons why the process was criticized, for example Amnesty International expressed fear that the Principles may be used by States to reinterpret their obligations under international law in a manner which risk to undermine $\mathrm{IHL}$ and IHRL and the protection of the human person. Amnesty International, 'Outcome of Copenhagen Process on detainees in international military operations undermines respect for human rights' $(23$ October 2012) at $<$ www.amnesty.org/en/documents/lOR50/003/2012/en/>.

73 Oswald, 'Some controversies of detention in multinational operations and the contributions of the Copenhagen Principles' [2013] 95 IRRC 707, 723.

${ }^{74}$ Drozd and Janousek v France and Spain App no 12747/87 (ECtHR, 22 June 1992) para 107.

75 For more information, see <www.unocha.org/where-we-work/current-emergencies>. See also Phil Orchard, A Right to Flee: Refugees, States and the Construction of International Cooperation (OUP 2014).
} 
world. ${ }^{76}$ Providing humanitarian assistance for persons in need has a strong basis on international humanitarian law, human rights law, refugee law, and international emergency law. ${ }^{77}$ The core principles of neutrality (not taking sides) and impartiality (provision of assistance with no regard to ethnicity, religion, race, or any other consideration, and proportional to need), plus the operational imperative (rather than a formal principle) to seek the consent of the belligerent parties have guided the provision of humanitarian assistance to persons in situations of armed conflict or humanitarian or other emergencies. ${ }^{78}$ As the ICJ put it in the Nicaragua case,

"[i]f the provision of "humanitarian assistance" is to escape condemnation as an intervention in the internal affairs of Nicaragua, not only must it be limited to the purposes hallowed in the practice of the Red Cross, namely "to prevent and alleviate human suffering" and "to protect life and health and to ensure respect for the human being"; it must also, and above all be given without discrimination to all in need... ${ }^{79}$

This finding of the ICJ emphasizes the basic requirements concerning the provision of humanitarian assistance, namely fulfilling basic human needs and non-adverse discrimination. These fundamental principles have been endorsed by the EU. ${ }^{80}$ First, humanitarian assistance is a right of the civilian population that is guaranteed under both $\mathrm{IHL}$ and human rights; second, states and humanitarian aid agencies have a legal basis for acting to ensure compliance with obligations stemming from this right; and third, humanitarian actors can offer humanitarian aid, with or without the consent of the parties to a conflict. ${ }^{81}$ Importantly, humanitarian workers are entitled to protection under IHL.

${ }^{76}$ For more information, see <https://ec.europa.eu/echo/what/humanitarian-aid_en>.

77 The main sources of refugee law are treaty law, notably the 1951 Convention relating to the status of refugees (adopted 28 July 1951, entered into force 22 April 1954) United Nations, Treaty Series, vol 189, 137 (hereafter 1951 Refugee Convention) and its 1967 Protocol (adopted 31 January 1967, entered into force 4 October 1967) United Nations, Treaty Series, vol 606, 267, and customary international law. Internally displaced persons (IDPs) are defined in the 1998 Guiding Principles on Internal Displacement as "persons or groups of persons who have been forced or obliged to flee or to leave their homes or places of habitual residence, in particular as a result of or in order to avoid the effects of armed conflict, situations of generalized violence, violations of human rights or natural or human-made disasters, and who have not crossed an internationally recognized State border".

78 See inter alia ICRC, 'Principles guiding humanitarian action' [2015] 97(987/8) IRRC.

79 Military and Paramilitary Activities in and against Nicaragua (Nicaragua v United States of America) (Merits) [1986] ICJ Rep 4, 125, para 243.

80 See inter alia European Commission, 'The European Consensus on Humanitarian Aid' (26 January 2018) $<$ http://ec.europa.eu/echo/who/humanitarian-aid-and-civil-protection/european-consensus_en>.

Paragraph 16 of this document emphasizes that 'The EU will advocate strongly and consistently for the respect of International Law, including International Humanitarian Law, Human Rights Law and Refugee Law'.

81 See inter alia Ruth Abril Stoffels, 'Legal regulation of humanitarian assistance in armed conflict: Achievements and gaps' [2004] 86 IRRC 515, 515-545; Rebecca Barber, 'Facilitating humanitarian assistance in international humanitarian and human rights law' [2009] 91 IRRC 371, 371-397; HansJoachim Heintze and Andrej Zwitter (eds), International Law and Humanitarian Assistance: A Crosscut Through Legal Issues Pertaining to Humanitarianism (Springer 2011); Amrei Müller, The Relationship between Economic, Social and Cultural Rights and International Humanitarian Law: An Analysis of HealthRelated Issues in Non-International Armed Conflicts (Martinus Nijhoff Publishers 2013) 239-270. 
In his 2014 Report on the Responsibility to Protect, the UN Secretary-General has addressed the protection of refugees and the internally displaced, as well as on the protection of civilians in humanitarian emergencies. The Report notes that in situations of crisis, the Office of the United Nations High Commissioner for Refugees (UNHCR), sometimes working in collaboration with non-governmental organizations such as the Norwegian Refugee Council, can offer concrete forms of protection by supporting requests for asylum or protecting refugees in safe facilities. ${ }^{82}$ With regard to protection of civilians in humanitarian emergencies, the Report notes that both on the field and global levels, humanitarian actors undertake coordination and protection efforts under the framework of the humanitarian protection clusters. This assistance not only enhances national efforts to protect populations at risk, but also contributes to mitigating conditions conducive to the commission of atrocity crimes. ${ }^{83}$

In more recent years, national governments, humanitarian agencies, and other actors have had serious difficulties in carrying out the legal obligations incumbent upon them. Despite their legal obligations, parties to armed conflicts often have denied access to humanitarian aid agencies. Access for humanitarian relief to civilians in need is a rule of customary IHL, applicable to both types of armed conflict. ${ }^{84}$ Parties to an armed conflict, that is both states and non-state armed groups, must allow and facilitate rapid and unimpeded passage of humanitarian relief for civilians in need, which is impartial in character and conducted without any adverse distinction. ${ }^{85}$ However, this broad legal protection is affected in practice by problems with getting access, as well as certain shortcomings of standard practices of aid agencies. The denial of humanitarian assistance as a crime under international law covers both the right to access and provision of humanitarian assistance, as well as protection for humanitarian workers and their equipment. ${ }^{86}$ Such denial of access in certain cases could amount to the war crime of starvation.

\section{Reparations for Serious Violations of Human Rights and Humanitarian Law}

The past decades have demonstrated a trend of claims for reparations and remedies related to harm resulting from conduct undertaken in armed conflicts and other military operations. In several cases discussed above, the ECtHR has found violations of the ECHR and ordered the responsible state to pay compensation. This part will describe the ECHR regulation on just

\footnotetext{
82 Report of the Secretary-General, 'Fulfilling our collective responsibility: international assistance and the responsibility to protect' (11 July 2014) UN Doc A/68/947-S/2014/449, para 65.

${ }^{83}$ Fulfilling our collective responsibility: international assistance and the responsibility to protect, para 66.

84 See Rule 55 of the 2005 ICRC CIHL Study 'Access for Humanitarian Relief to Civilians in Need', available at <www.icrc.org/customary-ihl/eng/docs/v1_cha_chapter17_rule55>.

85 Ibid.

${ }^{86}$ See inter alia Christa Rottensteiner, 'The denial of humanitarian assistance as a crime under international law' [1999] 835 IRRC, at <www.icrc.org/eng/resources/documents/article/other/57jq32.htm>; Phoebe Wynn-Pope, 'Humanitarian access in international humanitarian law: The case of Syria and Security Council Resolution 2139 (2014)' in Jadranka Petrovic (ed), Accountability for Violations of International Humanitarian Law: Essays in Honour of Tim McCormack (Routledge 2015) 117-135.
} 
satisfaction and examine the practice of the ECtHR in determining monetary compensation for non-pecuniary damage in selected cases related to multinational military operations.

State responsibility under international law entails that a state is obliged to remedy violations of international law by reparation when the act or omission is attributable to that state and there are no reasons precluding wrongfulness. ${ }^{87}$ Specific IHL obligations under treaty and customary law provide that states are to make reparations in the form of compensation for violations of IHL. ${ }^{88}$ The IHL obligation involves an underlying presumption of inter-state claims. ${ }^{89}$ Over time, arguments have been advanced that a customary right of individuals to reparations for damage by violations of IHL have emerged, or is about to do so. ${ }^{90}$ This development is heavily influenced by IHRL, where the right to remedies is essential, and may also be seen as a sign of convergence between the two areas of law. This is further illustrated by the UN Basic Principles and Guidelines on the Right to a Remedy and Reparation for Victims of Gross Violations of International Human Rights Law and Serious Violations of International Humanitarian Law (Basic Principles). ${ }^{91}$ The Basic Principles is a non-legally binding instrument of soft law which was intended to guide reparations to victims of armed conflicts who had suffered harm by violations of IHL and IHRL, but not to create new obligations. In effect, they do demonstrate the trend towards convergence

87 Article 1 UNGA Res 56/83 (12 December 2001) Articles on Responsibility of States for Internationally Wrongful Acts (hereafter ARSIWA). The Permanent Court of International Justice (PCIJ) famously held in the Chorzow Factory-case that; '[i]t is a principle of international law, and even a general conception of law, that any breach of an engagement involves an obligation to make reparation.' The Chorzow Factory Case (Germany v Poland) PCIJ Rep Series A No 9, 29.

88 Article 3 Hague Convention IV Respecting the Laws and Customs of War on Land and its Annex: Regulations concerning the Laws and customs of War on Land (adopted 18 October 1907, entered into force 26 January 1910) 36 Stat 2277, TS No 539. Article 91 AP I. The obligation to make reparations is also implied in the Grave Breaches regime of the Geneva Conventions, according to which States cannot absolve themselves or another High Contracting Party of any liability incurred in respect of grave breaches; article $51 \mathrm{GC}$ I, article $52 \mathrm{GC}$ II, article $131 \mathrm{GC}$ III, article $148 \mathrm{GC}$ IV It is widely held that these rules have developed in scope and now form part of customary international law. See ICRC and others (eds), Commentary on the Additional Protocols of 8 June 1977 to the Geneva Conventions of 12 August 1949 (ICRC, Martinus Nihjhoff Publishers 1987) para 3645; L. Zegveld and F. Kalshoven, Constraints on the Waging of War (ICRC 2001), 147; M. Sassoli in C. Bassouni (ed), International Protection of Victims (Éres 1988) 1165; Christine Evans, The Right to Reparation in International Law for Victims of Armed Conflict (Cambridge University Press 2012) 33. The treaty law of NIAC lacks a similar provision on reparations, which has been criticized as constituting a 'major lacuna' in IHL. Ibid, 31. According to the ICRC, Customary International Humanitarian Law Database on Rules and Practice, however, the customary international law rule on reparations is applicable both in IAC and NIAC, see rule 150.

${ }^{88}$ Evans, The Right to Reparation in International Law for Victims of Armed Conflict (n 87) 31.

89 ICRC and others (eds), Commentary on the Additional Protocols of 8 June 1977 to the Geneva Conventions of 12 August 1949 (n 87) commentary to article 91, paras. 3645-3661.

90 See Evans, The Right to Reparation in International Law for Victims of Armed Conflict (n 87) and Paola Gaeta, 'Are Victims of Serious Violations of International Humanitarian Law Entitled to Compensation?' in Orna Ben-Naftali (ed), International Humanitarian Law and International Human Rights Law: Pas de Deux (OUP 2011).

${ }^{91}$ Basic Principles and Guidelines on the Right to a Remedy and Reparation for Victims of Gross Violations of International Human Rights Law and Serious Violations of International Humanitarian Law, adopted by UNGA Res 60/147 (16 December 2005) UN Doc A/RES/60/147. 
of $\mathrm{IHL}$ and IHRL in this regard. ${ }^{92}$ The principal difference between the two areas of law in this respect is their institutional mechanisms. The evident lack of IHL bodies to which individuals have standing has led them to turn to human rights bodies to seek remedies for injury resulting from armed conflicts. This tendency is perhaps particularly evident in the European legal context.

The ECHR provides a right to remedies ${ }^{93}$ and possibilities for individual complaints of human rights violations with claims of just satisfaction. ${ }^{94}$ These provisions form an integral part of the protection of the rights and freedoms in the Convention, but the ECtHR is not intended to function as a tort mechanism and has been careful in how it decides on damages. The ECtHR has emphasized the obligation of the wrongdoing states to cease ongoing violations and remedy harm. In the case of Akdivar and other $v$. Turkey, it stated that 'a judgment in which it finds a breach imposes on the respondent State a legal obligation to put an end to such breach and make reparation for its consequences in such a way as to restore as far as possible the situation existing before the breach (restitutio in integrum)'. ${ }^{95}$ However, the ECtHR has continuously rejected ordering punitive damages aimed at forcing states to comply with their ECHR obligations. ${ }^{96}$ Instead it has relied on the Committee of Ministers to act in accordance with Article 46 ECHR and supervise compliance with its judgments. ${ }^{97}$ The regular practice of the ECtHR is to reviews claims of just satisfaction in connection to its findings of violations and order pecuniary and nonpecuniary damages. Article 41 ECHR provides that the Court shall, if necessary, award just satisfaction to the injured party when it has found a violation of the Convention (or its Protocols), but only if the domestic law of the responsible state merely allows for partial reparation. ${ }^{98}$ Thus, an order of just satisfaction depends on the Court's decision that it is necessary in the specific case and that it is not possible to get full reparation within the domestic system. As this indicates and as the ECtHR has pointed out, it is not a tort mechanism but serves a different purpose and

92 Evans, The Right to Reparation in International Law for Victims of Armed Conflict ( $\mathrm{n} 87$ ) 5.

${ }_{93}$ Article $13 \mathrm{ECHR}$ set out the right to an effective remedy and article 3 Protocol 7 to ECHR set out a right to remedies for arbitrary detention and miscarriage of justice. Comparable rights exist in several other rights treaties, eg article 2.3 ICCPR (right to an effective remedy).

${ }^{94}$ Article 34 and 41 ECHR.

${ }^{95}$ Akdivar and Others v Turkey (Article 50) App no 21893/93 (ECtHR Grand Chamber Judgment, 1 April 1998) (hereafter Akdivar $v$ Turkey) para 47.

${ }_{96}$ Cable and Others $v$ the United Kingdom App no 24436/94, 24582/94, 24583/94, 24584/94, 24895/94, 25937/94, 25939/94, 25940/94, 25941/94, 26271/95, 26525/95, 27341/95, 27342/95, 27346/95, 27357/95, 27389/95, 27409/95, 27760/95, 27762/95, 27772/95, 28009/95, 28790/95, 30236/96, 30239/96, 30276/96, 30277/96, 30460/96, 30461/96, 30462/96, 31399/96, 31400/96, 31434/96, 31899/96, 32024/96 and 32944/96 (ECtHR Grand Chamber Judgement, 18 February 1999) (hereafter Cable v UK) para 30; Orhan $v$ Turkey App no 25656/94 (ECtHR, 18 June 2002) para 447-449, Varnava and Others $v$ Turkey App no $16064 / 90,16065 / 90,16066 / 90,16068 / 90,16069 / 90,16070 / 90,16071 / 90,16072 / 90$ and 16073/90 (ECtHR Grand Chamber Judgment, 18 September 2009) (hereafter Varnava v Turkey) para 223. See also

${ }_{97}$ Akdivar v Turkey (n 95) and Varnava v Turkey (n 96) para 222.

98 Previously article 50. 
therefore has a different function. ${ }^{99}$ The Court therefore decides damages upon what is fair in the overall context. ${ }^{100}$

Applicants shall, according to the Rules of Court, establish whether their application includes a claim of just satisfaction. ${ }^{101}$ If no such claim is properly made, including when an application merely indicates a wish for reparations, the ECtHR normally does not examine damages under Article 41 ECHR. ${ }^{102}$ However, this practice may be sidestepped in exceptional circumstances. In Nagmetov v. Russia, the Court held that Article $41 \mathrm{ECHR}$ is hierarchical to the Rules of Court and Practice Directions on just satisfaction, and found that it had the discretion to award compensation also in the absence of a properly made claim. ${ }^{103}$ The prerequisites would be that the applicant had indicated a wish for reparations, that there was a causal link between violation and the nonmaterial harm, and that there were compelling reasons. ${ }^{104}$ Compelling reasons involve two elements; (i) 'particular gravity and impact of the violation, and overall context of the case', determined e.g. by its degree or nature based on the circumstances of the case; reflecting the overall objective of the Convention to protect fundamental human rights, ${ }^{105}$ and (ii) 'unavailability or partial availability of adequate reparation at domestic level'; reflecting the (subsidiary) nature of Article 41.106

Just satisfaction under Article $41 \mathrm{ECHR}$ may be limited to the judicial finding of a violation of the ECHR but may also include pecuniary damage, non-pecuniary damage, and compensation for costs and expenses. The Court has largely distinguished between two types of situations in examining whether damages should be awarded or not; (i) where the applicants' suffering and/or trauma is manifest, in which case damages are warranted, and (ii) where the judgment with a finding of a violation by the state (and the injury caused to the applicant) in itself is sufficient as just satisfaction, thus no damages are awarded. ${ }^{107}$ The first type of situations typically involves 'physical or psychological, pain and suffering, distress, anxiety, frustration, feelings of injustice or humiliation, prolonged uncertainty, disruption to life, or real loss of opportunity' caused by the violation. ${ }^{108}$ The other category typically involves less individual suffering and often concerns

99 Varnava v Turkey (n 96); Al-Skeini v UK (n 35) para 114. For in-depth analyses of the ECtHR's overall practice on just satisfaction see Octavian Ichim, Just satisfaction under the European Convention on Human Rights (Cambridge University Press 2015) and Attila Fenyves and Walter Berka, Tort law in the jurisprudence of the European Court of Human Rights (De Gruyter 2011).

100 Varnava v Turkey (n 96); Al-Skeini v UK (n 35) para 114.

101 Rule 60, Rules of Court, as amended by the Registry of the Court (ECtHR), 19 September 2016, Strasbourg.

102 Nagmetov $v$ Russia App no 35589/08 (ECtHR Grand Chamber Judgment, 30 March 2017) (herefter Nagmetov $v$ Russia) para 59.

103 Ibid para 74.

104 Ibid paras 79-80.

105 Ibid para 81.

106 Ibid para 82.

107 Varnava $v$ Turkey (n 96) para 224.

108 Ibid. See for example, Elsholz v Germany App no 25735/94 (ECtHR Grand Chamber Judgment, 13 July 2000) para 68-71 (distress and anxiety); Selmouni v France App no 25803/94 (ECtHR, Grand Chamber Judgement, 28 July 1999) para 120-123 (pain and suffering); and Smith and Grady $v$ the United Kingdom App no 33985/96 and 33986/96 (ECtHR, 25 July 2000) para 10-13 (devastation, distress and humiliation). 
legislation, procedures, or practices that do not comply with ECHR obligations. In judgements concerning the latter type of situations, the Court often makes a statement that the responsible state is to take measures to amend the situation so that it complies with obligations under the ECHR. ${ }^{109}$

The ECtHR's guiding principle in determining specific sums of damages is equity. The Court has held that equity 'involves flexibility and an objective consideration of what is just, fair and reasonable in all the circumstances of the case, including not only the position of the applicant but the overall context in which the breach occurred'. ${ }^{110}$ All circumstances should be assessed, e.g. it has implications if the applicant contributed to the situation or could have eased the situation or reduced the harm. ${ }^{111}$ Assessment of moral damages pose special challenges as it cannot easily be quantified or calculated based on concrete facts, which is usually done in assessment of other damages. In the words of the Court, non-pecuniary damages aim to 'give recognition to the fact that moral damage occurred as a result of a breach of a fundamental human right and reflect in the broadest of terms the severity of the damage'. ${ }^{112}$ Also, if the parties to a case have reached an agreement before the Court has decided on just satisfaction, the Court shall verify that the agreement is indeed equitable. ${ }^{113}$ The principle of equity is also used by the ICJ when it determines this kind of reparations. The ICJ has also referred to human right bodies' case law, including the $A /$ Jedda case, when examining non-pecuniary damage for human rights violations which had caused harm to individuals. A notable difference is that in the Diallo case, the ICJ awarded a higher sum than that generally ordered by the ECtHR. ${ }^{114}$

In Elsholz and Selmouni the Court stated that it could not establish a causal link between the violation and parts of the claimed injuries/sufferings of the applicant, but that the applicant had indeed suffered personal injury by the violations and thus was entitled to non-pecuniary damages for that part.

109 Varnava v Turkey (n 96) para 224. Further, see for example, Cable v UK (n 96) 27-28; Christine Goodwin $v$ the United Kingdom App no 28957/95 (ECtHR, Grand Chamber Judgement, 11 July 2002) 116-120; and S. and Marper $v$ the United Kingdom App no 30562/04 and 30566/04 (ECtHR Grand Chamber Judgment, 4 December 2008) para 132-134. In both Goodwin and Marper the Court pronounced that it would be for the States in question to implement adequate measures to the effect that the rights of the applicants in the respective cases, as well as other affected individuals, be respected. (Eg in Goodwin (para 120): "It will be for the United Kingdom Government in due course to implement such measures as it considers appropriate to fulfil its obligations to secure the applicant's, and other transsexuals', right to respect for private life and right to marry in compliance with this judgment.") Thereafter the Court found that the finding of a violation of the ECHR and its consequences for the future were considered sufficient just satisfaction. See also Chahal $v$ the United Kingdom App no 22414/93 (ECtHR Grand Chamber Judgement, 15 November 1996) 157-158; and Saadi v Italy App no 37201/06 (ECtHR Grand Chamber Judgemet, 28 February 2008) para 182-188, where the Court found that its finding that the deportation of the applicant would be in violation of article $3 \mathrm{ECHR}$ and that this finding was sufficient as just satisfaction.

110 Al-Skeini v UK (n 35) para 182; Al Jedda v the United Kingdom (n 56); Varnava v Turkey (n 96) para 224; Nagmetov $v$ Russia (n 102) para 73.

111 See for example, The Estate of Nitschke $v$ Sweden App no 6301/05 (ECtHR, 27 September 2007) para 68-70. See also Elsholz $v$ Germany (n 108).

112 Al-Skeini v UK (n 35) para 182; Al Jedda $v$ the United Kingdom ( $\mathrm{n} 56)$ para 114; Varnava $v$ Turkey $(\mathrm{n}$ 96) para 224; Nagmetov $v$ Russia (n 102) para 73.

113 Rule 75.4 Rules of Court.

114 See Case Concerning Ahmadou Sadio Diallo (Guinea $v$ Democratic Republic of the Congo) (Compensation) [2012] ICJ Rep 324, para 24 citing Al Jedda $v$ the United Kingdom on the flexible and 
Turning now to how the ECtHR has assessed the specific sums of damages in two cases involving situations with a connection to a multinational military operation: Al Skeini and Jaloud. The applicants in both $A$ / Skeini and Jaloud had asked the ECtHR to remedy the violation by ordering the respective states to undertake an(other) investigation, compliant to the standards of Article $2 \mathrm{ECHR}$, into the respective relatives' deaths, and - in the case of Jaloud - to the extent possible, prosecute responsible persons while keeping the applicant informed. ${ }^{115}$ Further, the applicants in Al Skeini and Jaloud claimed non-pecuniary damage, and in both cases, the ECtHR found it equitable to award the respective amount which the applicants had claimed for the distress they had suffered because of the lack of an independent investigation into the deaths of their relatives. In Al Skeini this meant that the (first five) applicants were awarded 17,000 euros plus tax in non-pecuniary damage. ${ }^{116}$ In Jaloud, this meant 25,000 euros plus tax. ${ }^{117}$ As per usual, the Court ordered in both cases that the damage and compensation for costs and expenses was to be payed within three months, and, had it not been payed within this timeframe, simple interest would be payable in addition plus three percentage points. ${ }^{118}$ It is notable that the Court did not assess further what was an equitable amount in Jaloud, since it, similarly to Al Skeini, concerned the procedural obligations under Article $2 \mathrm{ECHR}$ within an extra-territorial armed conflict context but the applicant's claims for non-pecuniary damage differed. The Netherlands opposed the claim by emphasizing that this was higher than what the Court had awarded in Al Skeini, ${ }^{119}$ but the Court merely stated that - as in Al Skeini - it considered 'it equitable to award to the applicant the sum which he claims'. ${ }^{120}$

objective elements of equity in determining a reasonable amount in the overall context of the violation. The ICJ ultimately awarded an amount in Diallo which was notably higher than most human rights bodies have awarded for similar violations (including in cases cited by the Court). See Declaration by Judge Christopher Greenwood, para 9 and 11, to Case Concerning Ahmadou Sadio Diallo (Guinea v DRC), but much lower than what was claimed by Guinea. See a summary of Guinea's claim of 250000 US dollars for non-material damage in ibid para 10.

${ }_{115}$ Al-Skeini v UK (n 35) para 179 and Jaloud $v$ the Netherlands App no 47708/08 (ECtHR Grand Chamber Judgement, 20 November 2014) (hereafter Jaloud $v$ the Netherlands) para 232.

116 Al-Skeini $v$ UK (n 35) para 182. (Whereas the sixth applicant was no longer considered a victim of the relevant violation). The applicants had also claimed a total cost of 119,928 pounds for cost and expenses related to legal aid, which the UK claimed was excessive while agreeing that it was a complex case. Based on the documentation available and what the Court was deemed reasonable it set the sum to cover costs and expenses for legal aid to 50,000 euro plus tax. (Para 183-185).

117 Jaloud $v$ the Netherlands ( $n$ 115). The applicant had initially claimed compensation for costs for his lawyers, while maintaining that this was only relevant in case he would not receive domestic legal aid. In addition, a claim was made in regard to other expenses. The sum to cover expenses of his lawyers was set to $1,372.06$ euro plus tax, as the ECtHR assumed the applicant had received the domestic legal aid he had sought for the costs of his lawyers. (Para 236-240).

118 Al-Skeini $v$ UK (n 35) para 186 and Jaloud $v$ the Netherlands ( $n$ 115) para 241. See also rule 75.3 of the Rules of Court (ECtHR).

119 Jaloud $v$ the Netherlands ( $\mathrm{n} 115$ ) para 233.

${ }^{120}$ Al-Skeini v UK (n 35) para 179 and Jaloud $v$ the Netherlands (n 115) para 235. 
The ECtHR has developed its case law on just satisfaction on a case-by-case basis rather than thematically or systematically. ${ }^{121}$ This is also apparent from the cases of Al Skeini and Jaloudwhich had contextual similarities, but the Court did not compare the sum for non-pecuniary damages -that the fact that the violation was committed in the course of or related to an extraterritorial military operation had no particular impact as such on the decision on the specific sum of damages. The decisions on just satisfaction in the cases of Al Skeini and Jaloud demonstrate that the sum claimed by the applicant has a significant impact on the sum the Court settles on. The Court takes the claim as a starting point and assesses if it is reasonable based on the principle of equity in the overall context of the case. The non-pecuniary damages in these cases, plus what is awarded for costs and expenses, constitute a significant total sum for the state, but may not be seen as punitive damages - and are still lower than what the ICJ has awarded for reparations in a case of diplomatic protection of human rights.

\section{Concluding Remarks}

The substantive convergence between human rights and humanitarian law has been largely driven by shared core concerns, namely protecting human life and human dignity, providing humanitarian assistance, and reducing to the maximum extent possible the negative effects of armed conflicts. This ongoing process has become more prominent after the $1990 \mathrm{~s}$, due to an increased use of IHRL and IHL norms by judicial and non-judicial mechanisms at national, regional, and international levels. Given the paucity of enforcement mechanisms under IHL, individuals are likely to bring claims relating to military operations to human rights bodies, especially the ECtHR. European states have been involved in different multinational military operations, and issues concerning the right to life and detention have been raised in several cases. The fact that the ECHR applies extra-territorially when states exercise jurisdiction in the sense of Article $1 \mathrm{ECHR}$ involves a need to carefully address regional human rights obligations in multinational military operations. That is why the precise scope of substantive convergence between IHL and IHRL, in particular the ECHR, is important.

When humanitarian law safeguards are applied as their content requires, human rights and humanitarian law norms reveal a similar content. ${ }^{122}$ While the 'capture or kill' debate and the issue of the use of force in armed conflicts will continue to be prone to debate, it must be emphasized that the principles of distinction and proportionality and the prohibition of arbitrary killings are useful in safeguarding the right to life in armed conflicts. The ECtHR's approach to interpret, at least Articles 2 and $5 \mathrm{ECHR}$, in line with IHL as far as possible opens up for further convergence. Recent ECtHR case law has contributed to significant substantive convergence between the $\mathrm{ECHR}$ and IHL concerning the lawfulness of detention. Internment based on GC III and IV is

121 See for example Varnava $v$ Turkey (n 96). The applicants had based their claim of just satisfaction on other disappearances cases, but the Court held that there are no "specific scales of damages" for certain type of cases.

122 Alexander Orakhelashvili, 'The interaction between human rights and humanitarian law: Fragmentation, conflict, parallelism, or convergence?' [2008] 19 European Journal of International Law 182. 
considered lawful deprivation of liberty under the ECHR during IACs, with no need to derogate. ECtHR's findings in Hassan are, however, clearly focused on the particularities of IHL in IACs, meaning that there remains ambiguity as to whether detention in NIACs may be based on IHL. Given the lack of a treaty authorization and regulation of internment in IHL applicable in NIACs and the controversy as to whether CIHL in NIAC authorizes internment, it is likely to be a very different issue than in Hassan. In Hassan, the ECtHR confirmed its continuous practice that detention outside armed conflict is to be determined by the normal standards of Article $5 \mathrm{ECHR}$, which, in the absence of a derogation, means that administrative detention is not allowed.

The issue of reparations for victims of armed conflicts has received significant international attention and lip service, although that has not necessarily translated into more victims receiving reparations for injuries suffered. New rules and principles have emerged in human rights law and international criminal law, as applied by international courts. In addition, there have been significant developments under the human rights regime to address reparations to situations of armed conflicts, and there is a clear tendency to recognize the right of the individual to reparations for violations of international humanitarian law. The decisions on specific damages are made with the claim of the applicant as a starting point and assessed based on the principle of equity, a flexible concept involving a determination of what is fair and just in the specific case and with regard to the overall context. While the nature and context of a situation of armed conflict may have an impact on what is equitable in a particular case, the practice of the ECHR concerning reparations for serious violations in the context of multinational military operations remains underdeveloped. 